\title{
Kritikai racionalitás a másodlagos írásbeliség korában
}

A kritikai racionalitásnak tetemes hagyománya alakult ki a nyugati gondolkodásban. A tanulmány egyrészt e hagyomány gyökereire, másrészt pedig e hagyomány jelenleg folyó átalakulására, s annak okaira világít rá. A szerző sokban támaszkodik Hajnal István és a Hajnal munkásságának szerves folytatását jelentő Torontói Iskola írásbeliség-fogalmára, a filozófia történetében markáns formát öltő kritikai racionalitás bizonyos megnyilvánulásaira, valamint nyelvfilozófiai vizsgálódásokra és kognitív pszichológiai kutatásokra.

Kulcsszavak: filozófia, írásbeliség, kommunikáció, reprezentáció

\section{Szerzői információ:}

Kondor Zsuzsanna

Filozófus az MTA Filozófiai Kutatóintézetének tudományos fốmunkatársa. Fóbb kutatási területei: kommunikációfilozófia, a képi és a verbális reprezentáció kognitív különbségei és következményei. Legfrissebb publikációi: Old Patterns, New Bewitchments. H. Hrachovec-A. Pichler J. Wang (eds.): Philosophy of the Information Society. Papers of the $30^{\text {th }}$ International Wittgenstein Symposium. 2007, 109-111; Multimodal Integration. From a Philosophical Point of View. In: Immaculada Arnedillo-Sanchez (szerk.): Proceedings of the IADIS International Conference. Mobile Learning 2007, 119-126; Mobil kép - mobilizált tapasztalat. In: Nyíri Kristóf (szerk.) Mobiltársadalom-kutatás. Paradigmák - Perspektívák. Budapest, MTA/T-Mobile, 2007, 21-28.

E-mail: kondor@webmail.phil-inst.hu

Így hivatkozzon erre a cikkre:

Kondor Zsuzsanna. „, Kritikai racionalitás a másodlagos írásbeliség korában”.

Információs Társadalom VII, 4. szám (2007): 36-46.

$\mathbf{L}$

https://dx.doi.org/10.22503/inftars.VII.2007.4.2

A folyóiratban közölt müvek

a Creative Commons Nevezd meg! - Ne add el! - Így add tovább! 4.0

Nemzetközi Licenc feltételeinek megfelelöen használhatók. 
Kondor Zsuzsanna

\section{Kritikai racionalitás a másodlagos írásbeliség korában}

\section{Írásbeliség és kritikai racionalitás}

A kritikai racionalitás kialakulásának elemi feltétele volt az írás megjelenése és gondolkodásunk fontos közegévé válása. Hajnal a következóképpen foglalta össze az írás gondolkodásunkra gyakorolt hatását:

„A természetes, nyelvszerú gondolkozás és az írás [ezen] egybeolvadása egy új, írásbeli gondolattechnika kialakulását jelentette. Az írás az ember külsô-belsố életét elevenen kíséri, objektiválja, s ezzel megfigyelésre képessé teszi. Múltat és jelent mind az egyéni, mind a közösségi életben összekapcsolva, okszerú gondolkodásra ösztönöz, komplikált gondolatépítést tesz lehetốvé. A racionalizmus tulajdonképpeni kifejlôdésének gyakorlati alapja. [...] A kifejezóképesség növekedése teszi öntudatossá mind az általános emberit, mind az egyénit, hoz létre mindig hatványozott arányban közös fogalmakat, absztrakt gondolatokat" ('Technika, mïvelödés [1933] 1993, 43).

Hajnalnak ez a passzusa igen tömören foglalja össze az írás és a hozzá kapcsolódó kultúra múködési mechanizmusát leíró elméletét, illetve ennél általánosabban, a jelenségek szociológiai-történeti megragadásának szerinte lehetséges módját. ${ }^{1}$ Mindkét esetben az objektiváció fogalma képezi a kiindulópontot. Mielốtt azonban Hajnal objektivációelméletére térnék - amelynek alapján a kritikai attitûd szinte szükségszerúnek tekinthetô -, röviden vázolom a nyugati racionalitás létrejöttének körülményeit.

Hajnal s nyomdokain a Torontói Iskola, de különösképpen Walter J. Ong és Eric A. Havelock kutatásai alapján nyilvánvalóvá vált, hogy az írás megjelenésével és terjedésével az írás elớnyeinek és egyben a korlátaihoz való alkalmazkodásnak a jegyében új gondolattechnika alakult ki. Már Hérakleitosznál felfedezhetố bizonyos új nyelvezet, voltaképp az elvont fogalmiság iránti igény nyomai, ${ }^{2} \mathrm{~s}$ az igény és az íráshasználat hamarosan ki is alakította ezt az új nyelvezetet: Platón már olyan elvont fogalmak meghatározásán fáradozott, mint amilyen a szépség, a jóság stb. A megfelelố szókészlet hiánya mellett gondot okozott a kontextus megteremtése is. Az élőszó multimodális világát, amelyben számos információt nem nyelvi csatornákon dolgozunk fel, kizárólag a verbalitás keretei között lehet írásban közvetíteni. Ez időnként komoly nehézséget okoz: a lineáris elrendezés kényszere hatványozott erốvel jelentkezik, hiszen nemcsak a megosztandó tapasztalatokat kell sorba rendezni, hanem az adott kontextus egyes elemeit is. Miképp Hajnal is felhívja rá figyelmünket, a múltról való feljegyzések, a múlt írásos emlékei szinte felkínálták az összehasonlítást a jelenkori és a múltbéli konstellációk között, s persze lehetốvé tették a hosszú távú elméleti építkezést. A lineáris elrendezés feladata, illetve kényszere és az elvont, a gyakorlattól távoli fogalmak szintén a külsố szemlélő distanciált, analizáló látásmódját sugallják. E nehézségek enyhítésére

\footnotetext{
'Vö. Technika, mî́velö́dés [1939] 1993, 162/3.

${ }^{2}$ L. Kondor 2005a.
} 
számos módszertani és a módszertant megalapozó ismeretelméleti, mi több, metafizikai javaslat született.

Az írásbeliséghez kapcsolódó gondolattechnikát olyan alapvető hasadás határozza meg, amely hosszú távon állandó elméleti feszültséghez vezet: jelesül megbomlik a jelenségek és a jelenségek kognitív-kulturális processzálásának egysége. Mivel az élôszót leképezố néma jelek az áthagyományozásra érdemes tudást közvetítik, általános elveket igyekeznek közvetíteni, a mindennapi, egyedi esetek legfeljebb illusztrációként szolgálnak. ${ }^{3} \mathrm{Az}$ írás mint ,idóben kitartott közlés” ${ }^{4}$ lényegében a mindennapok világa fölé emelkedve, attól elszakadva igyekszik a mindennapok során kikristályosodott tudást megórizni. Ez csak akkor lehetséges, ha a szerzố nem résztvevóként, hanem külsố szemlélóként kellő distanciávabỳiseltet a világ jelenségei iránt. A filozófia története során ez az attitúd egyre határożottabb kifejezést nyer.

Az írott szöveg tehát funkciója és adottságai által gyökeresen új attitûdöt alakított ki, amelyet az íráshoz és olvasáshoz kapcsolódó, a nyomtatás megjelenésével radikális változáson keresztülmenó rutin is megerôsített.

Nagyon jól látszik Platón írásbeliségkritikáján az írásbeliség által sugallt beállítódás, s az elmélettel szembeni elfogultság: Az írás inhumánus, mivel úgy tesz, mintha a tudást az elmén kívül is megalapozhatná, holott az csak az elmében létezhet; az írás valamiféle készítmény, az írott szövegek csupán „emlékeztetók azok számára, akik ismerik a szóban forgó tárgyat”, s ezen ismeret csak beszélgetések által szerezhetố meg. ${ }^{5}$ Tehát a töprengés - és tegyük hozzá, Platón idejében még az aktív, szemtól szembeni párbeszéd - gyümölcseként érvek és ellenérvek során kibontakozó tudás külsôdleges eszközök segítségével nem közvetíthetô. Akárcsak az ideák és az árnyképek világa, a „lélekbe íródó igaz ismeretek” és a külvilág dolgai élesen elkülönülnek egymástól. Ami a jelen vizsgálódás szempontjából különös jelentôségú, az a tudásnak és a gondolkodásnak a lélekhez való kapcsolása. Lényegében már itt megjelenik a fizikai és szellemi/lelki világ elkülönítése, ami a nyugati metafizika 2500 éve alatt lényegében permanens kihívást jelentett a filozófia számára. Ez a dualitás sajátos egyoldalúságot eredményezett az elméletalkotásban, és meghatározó befolyással volt a változások kezelésére. A megismerố elme világtól való elszakítottsága nem tette lehetôvé, hogy a gondolkodást és an-

\footnotetext{
${ }^{3} \mathrm{~V}$ ï. az Ivins által a képek sokszorosíthatóságának technikai korlátai és az általánosságokban való gondolkodásra való hajlam között kimutatott összefüggéssel. Ivins 2001, különösképp 60 sk.

4 „A szóbeli megnyilatkozás világa jellemzően a diskurzus világa, a diskurzusban az egyik megnyilatkozás elôidéz egy másikat az megint egy másikat, és így tovább. A jelentés a diskurzusfolyamatban bontakozik ki. [...] A szöveg minden bizonnyal elválasztja a megnyilatkozást szerzőjétól [...] Az írás ebben az értelemben autonóm diskurzust teremt. Ám a megnyilatkozás szerzőjétốl történô eltávolítása nem jelenti a megnyilatkozás diskurzusból történő eltávolítását. Diskurzuson, tranzakcionális beágyazáson kívül megnyilatkozás nem létezhet. Az írásba foglalás csak megszakíthatja a diskurzust, idôben és térben pedig a végtelenségig nyújthatja a megnyilatkozást" (Ong 1998, 144).

${ }^{5}$ Phaidrosz 278a (Platón II, 1984, 804). Vö. „Nekem legalábbis semmiféle munkám nincs a legfóbb kérdésekról, és nem is lesz soha. Hiszen a végső belátást nem lehet szavakkal kifejezni, miként az oktatás szokásos tárgyait: az érte szakadatlanul végzett közös munka és az igazi életközösség eredményeként egyszerre csak felvillan a lélekben - akárcsak egy kipattanó szikra által keltett világosság-, s azután már önmagától fejlódik tovább" VII. levél, 341d (Platón III, 1984, 1066). E passzus természetesen többet mond annál, mint hogy az igaz tudás a szóbeli ćrintkezés által, közösen, másokkal együtt nyerhetô. A „végsố belátás” artikulálhatatlanságának problémáját érinti.
} 
nak reprezentációs közegét kölcsönhatásban fogják föl. Épp ezért mind az írás, mind a nyomtatás feltalálásának esetében inkonzisztens módon, de a fennálló gondolattechnikák védelmében éltek kritikával az adott invencióval szemben. Sajátos tudathasadásos állapotot tükröz ez a kritikai attitûd, mely egyébként az élettel való konfrontáció alkalmával rendre tapasztalható (gondolhatunk társadalomfilozófiai, etikai kérdésekre, melyek gyakorta nehezen összeegyeztethetốk metafizikai és ismeretelméleti elófeltevésekkel). ${ }^{6}$

A nyelv bizonyos torzító mechanizmusai, ${ }^{7}$ továbbá az írott nyelv markáns korlátai állandó mentális kényelmetlenséget okoztak. Épp ezért a nyelv korrekciójának igénye, a megfelelő módszer megadása és a logika csiszolása - mintegy a nyelvból adódó nehézségek kiküszöbölése érdekében - meghatározó törekvések voltak a filozófia története során. Az analizáló, logikai-matematikai eljárásmódokat követô módszertan természetéból adódott, hogy megnyugtató eredmény híján újabb és újabb kísérletek történtek az elózó megoldások meghaladására. A filozófia története voltaképp e javító szándék története: Hogyan lehetne egységes, ellentmondásoktól mentes elméletet alkotni, amely képes a világ jelenségeit egységben kezelni?

Ilyen körülmények között nem meglepó tehát, ha a gondolat kifejezésének eszközeiben bekövetkező változást gyakorta kísérte ellenérzés: az épp meghatározó gondolattechnikákat, melyeket korántsem ítéltek kielégítốnek, a kommunikációtechnológia új eszközei lényegében újabb kihívásokkal szembesítették. ${ }^{8}$

A kritikai attitúd természetesen a 20. századot is jellemezte, s mi több, a gondolatartikuláció módjának változásával kapcsolatban is explicit formát öltött. E tény nyilván összefügg a technika fejlődésével, amennyiben a megörökítés/áthagyományozás és megốrzés számos új módja vált lehetségessé. Lehetett rögzíteni a képet, a hangot, lehetségessé vált a telekommunikáció. Ifjabb William M. Ivins A nyomtatott kép és a vi氵uális kommunikáció címú könyvében nagyszerú összefoglalását adja a szó és kép rögzíthetốvé válásának fáziseltolódásából adódó gondolkodásmód-változásnak $\mathrm{s}$ annak a nehézkes átállásnak, amely a képek birodalmának újbóli meghódítását jelenti.

\section{A kritikai racionalitás szükségszerüsége}

Visszatérve Hajnal elméletéhez, mely a saját korát illetố kritika tekintetében számos kortárs véleményével csengett össze, röviden kitérek Hajnal objektivációelméletének ismertetésére. ${ }^{9}$ Akár az emberi kultúra, akár a társadalomszervezôdés, akár az emberi gondolkodás folyamatáról essék szó, Hajnal az objektivációkon keresztül igyekszik azokat megragadni és egységben kezelni.

${ }^{6}$ L. Kondor 2005b.

${ }^{7}$ L. alább, valamint Kondor 2007.

${ }^{8}$ A nyomtatás megjelenésekor például Hieronimo Squarfiafico (1477) clítélte a nyomtatott könyvet, mert úgy vélte, hogy a könyvek sokasága rontja az ember szorgalmát, rombolja memóriáját, és leértékeli a bölcs öregek tekintélyét. Érvei hasonlítanak az írással szemben megfogalmazott platóni érvekre (Ong 1982, 80).

${ }^{9}$ Az objektivációelmélet a 20. század eléjén igen elterjedt modell volt. L. különösen a Hajnal által igen sokra tartott Hans Freyer munkásságát, de a talán manapság ismertebb, noha Hajnal által nem idézett Oswald Spengler is ide sorolható, nem beszélve az Alfred Weber által kidolgozott kultúrszociológiáról. 
Az objektiváció igen sajátos mechanizmusa révén egyfelól támasztékkal és a fejlôdés lehetốségével szolgál, másfelól pedig tetemes korlátokat állít utunkba. Az objektivációnak az emberi gondolkodásra, s természetesen a társadalom szervezódésére gyakorolt hatását így összegzi Hajnal:

„Az állattal szemben az ember mint valami gazdagon felszerelt, lelki élményeit kifejezésekkel támogató pszichofizikai múszer jelenik meg.

Talán már ez is a szociális fejlódés eredménye. [...] Csodálatos ténye az emberi természetnek; az anyagi formákhoz való kapcsolódással mintegy »kiteszi « az élményt az aktuális lelki mozgalomból, s ezzel mintegy "úrrá lesz rajta «. A taglejtés, sírás, nevetés »megkönnyebbít «. Az eleven élet lüktetve »polarizálódik « valami anyagi támaszték felé, hogy megállhasson magával az élettel szemben; a psziche mintegy partra szállva szemléli az élet áramlását, s így sejti meg annak örökkévalóságát.

E belsó objektivációs rétegeken, a tudatlan és mégis létezô formákon át küzdi fel magát az élmény a tulajdonképpeni objektivációkig, a kifejezésmozgások felhasználásával. Az önkéntelen mozdulat vagy kiáltás most már eljárásmódnak tûnik fel elótte belsố élményének anyagi-formai kapcsolására, segítésểe. [...] A forma módot ad az élmény tárgyi kapcsolódására, ez a funkciója; a tartalom, a fogalom változatos értelemmel jelentkezhetik.

Itt azonban eljutottunk a »szociális « objektivációkig. Ember s ember kifejezésmozgások útján kezdi megérteni egymást, pszichofizikai természetük alapján. [...] A mozdulatokból, köztük a hangokból is, »érthetơ «, »konvencionális « jelek keletkeznek [...]" (Technika, múvelódés [1939], 1993, 179).

Az építkezéshez szükséges „anyagias támaszték” létrejötte ugyanakkor idegen, újfajta mechanizmusokat hoz létre: „Mihelyt kifejez valamit az ember, célszerúbben tudja már kezelni, bár életteljes gyökereit megszakítva" (Technika, múvelödés [1939], 1993, 179). Voltaképpen ezen a felismerésen nyugszik Hajnal történetfilozófiája, de korának kritikája is. Hajnal saját korát a kiürülés korszakának tekinti, amikor is az objektivációk avagy struktúrák ${ }^{10}$ mechanizmusai kerekednek felül az organikus igényeken, amelyek tulajdonképpen létrehozták azokat.

„Minden kultúra sorsa idővel az elmúlás. [...] Nagy kultúregységek egyes részeiben hasonló váltakozása az objektív struktúrák felépülésének és további alkotásra képtelen elmechanizálódásuknak. Ez a sorsuk maguknak a nagy kultúregységeknek is.

Mert minden objektiváció: bizonyos egyoldalú elvonatkozás az élmény életteljességétól" (Technika, müvelódés [1939], 1993, 189).

A történetfilozófiai korszakolás szempontja mellett Hajnal kritikája, mely egyben az írásbeliség kritikája is, rámutat magában az írásbeliségben rejlő veszélyekre is.

10 „Struktúra: minden objektív kifejezốdés; tehát hozzátartoznak azon pontok is, amelyek az egyéni élményben az anyaghoz-formához való kapcsolódást jelentik, s amiket a közfelfogás és a filozófia is az individuálisnak, a szubjektívnak szférájához sorol, szemben a teljesen objektivált, személytôl elvált formákkal" (Technika, mîvelödés [1939], 1993, 185). 
Saját korát olyan kornak tekinti, amelyben az írásbeliségben kialakuló gondolkodásés szemléletmód elszakad a mindennapok világától, s mintegy önmagába zárkózva, az élettôl idegenné válva és saját mechanizmusainak kiszolgáltatva voltaképpen kiüresedik.

„Betú termelte a betút, írás az írást. A csupasz spekulatív gondolkodás a legkisebb feladatokban is finoman múködött, s annál tökéletesebben, minél egyoldalúbb, mechanikusabb részletekre vonta szét a hivatásokat, mentesítette óket az élet súlyos anyagának érzékelésétól" (Technika, müvelódés [1948], 1993, 449).

A szövegek világa nem gyarapodhatnék emberi hozzájárulás nélkül, de az indíttatás egyre inkább a szövegekkel kapcsolatos kényszerból születik meg, s nem a mindennapok világával való érintkezésból. Hajnal a modern kultúrát mint „betûnarkózistól” szenvedő kort jellemzi, amiból az egyetlen kiutat „az élmények, tapasztalatok valódiságához" való visszatérés jelentheti.

\section{A másodlagos írásbeliség noetikus világa}

Az „élmények, tapasztalatok valódiságához” való visszatérés technikai-technológiai feltételei lényegében mára adottak: képet, hangot, szöveget, s még sorolhatnánk ezek aleseteit, képesek vagyunk szinte bármikor, bárhonnan mások számára hozzáférhetôvé tenni. Tehát, ha valakinek szeretnék beszámolni az örömról, amelyet egy meglepetés éppen okoz, nem feltétlenül kell szavak segítségével körülírni az esetet: spontán videofelvétel, esetleg néhány kép és szó igen gazdag információval szolgálhat a távol lévố számára. A másodlagos írásbeliség korát pedig éppen ez a lehetôség különíti el az elôző idôszaktól. Eltérốen Walter J. Ong terminológiájától, " a másodlagos írásbeliséget olyan korszaknak tekintem, amikor az írásbeliség racionalitása kiegészül a multimodális kommunikáció lehetôségével. Ez annyit jelent, hogy a tapasztalatok és a tudás rögzítésének és megosztásának számos módja könnyen hozzáférhetố, azaz nem szükséges feltétlenül írásos feljegyzéseket készíteni, s ezáltal újrastrukturálni a közlendóket, ami egyben azt is jelenti, hogy lényegében eleven, elsődleges élményként adható tovább a megốrzendő, illetve közvetítendő információ. Lehetségessé válik, hogy közvetlenül hozzáférjünk ahhoz, ami korábban több interpretációs lépcsôn keresztül volt csak közvetíthetố, azaz a közvetítés mozzanata már-már eliminálódik.

Mivel gondolkodásunkat tetemes mértékben befolyásolja a gondolat kifejezésének módja, joggal várhatjuk, hogy a másodlagos írásbeliség adta technikai-technológiai lehetôségek sem maradnak hatás nélkül. Az alábbiakban a kognitív múködés néhány jellegzetességére térek ki röviden, különös tekintettel a nyelvi reprezentáció sajátosságaira. Ennek során sokban támaszkodom a George Lakoff által adott modellre, valamint a vizuális elme reprezentációs elméletére, amelyet Pierre Jacob és Marc Jeannerod dol-

"A másodlagos írásbeliség vonatkozásában 1. W. J. Ong „Schmandt-Besserat on Writing and Consciousness - Ong Sessions at MLA 2006 and CCCC 2007. Ong on Secondary Orality and Secondary Literacy": http://ongnotes.slu.edu/?p=190; továbbá a „Secondary Orality and Secondary Visualism”:

http://libraries.slu.edu/sc/ong/digital/texts/lectures/lecture1.pdf. 
gozott ki. Mindkét megközelítés a nyelv, illetve a fogalmi gondolkodás gyakorlatba ágyazottságát és motoros gyökereit emeli ki.

Lakoff, Jacob és Jeannerod kognitív készségeinket és múködésünket illetố leírásai természetesen a modern emberre vonatkoznak, s dacára a ténynek, hogy elvont fogalmiság jellemzi gondolkodásunkat, azt igazolják, hogy az elemi tapasztalatok jelentősége - szemben az írásbeliség kultúráján nevelkedett bölcsész meggyőződésével - mit sem változott.

Lakoff egyik fố célkitû́zése, hogy a kategóriák létrejöttének és múködésének megértésével közelebb kerüljünk kognitív múködésünk feltárásához. Anélkül, hogy a kategorizációt érintố részletekbe bocsátkoznék, igyekszem Lakoff azon nézeteit összefoglalni, amelyek közvetlenül érintik a nyelvról alkotott elképzelésünket új megvilágításba helyezố filozófiai megfontolásokat.

Lakoff megkülönbözteti a prekonceptuális és a fogalmi szintet, mégpedig azok strukturális meghatározottságai alapján. Az elóbbit az alapszintú kategóriák, illetve kinetikus vázlatos képi struktúrák határozzák meg. Az alapszintú kategóriák sajátossága, hogy igen korán kialakulnak, s szerepük egyaránt meghatározó a mindennapi, sốt bármilyen tudományos aktivitás esetén is. Ez nem véletlen, hiszen e kategóriák jelentik az általánosságnak azt a szintjét, ahol a motoros tevékenység egyértelmú szervezóje a tapasztalatoknak, s a megtanulhatóság és a memória szempontjából nem jelentenek túl nagy megterhelést. (A szék alapszintú kategóriájához egyértelmúen kapcsolódik egy bizonyos mozdulatsor, gyors tájékozódásra ad lehetóséget, s nem jelent olyan memóriaterhelést, mint a különféle széktípusok elkülönítése; valamint nem követel olyan emelt szintû́ absztrakciót sem, mint például a bútor egy szinttel följebb lévô kategóriája, ahol is egyértelmú motoros aktus nem társul a kategóriához. $)^{12} \mathrm{Az}$ alapszint persze nem valamiféle primitív egyszerúséget, strukturálatlanságot jelent. Éppenséggel gazdagon strukturált. Prekonceptuális szinten ugyan az alapszintű kategóriák Gestaltként, azaz egészlegesen, általános átfogó formaként jelennek meg, de a belsố struktúra is azonosítható bennük. Hangsúlyoznunk kell, hogy - szemben a klasszikus kategóriaelmélettel az alapszintű kategóriák nem atomi építőelemekként múködnek (hiszen van belsố struktúrájuk és a kategóriák hierarchiájában nagyjából középtájt helyezkednek el).

A kinetikus vázlatos-képi struktúra a testi tapasztalatok összefoglaló neve, amely tehát alapvető viszonyokat foglal magában, mint például kint-bent, rész-egész, kapcsolódás, centrum-periféria, forrás-ösvény (ami tulajdonképpen térbeli irányokról, mozgásokról ad képet), fönt-lent, elöl-hátul, valamint bizonyos linearitás. E viszonyok középpontjában a testünk áll, s jelentőségüket motoros tevékenységünk által nyerik. ${ }^{13}$

Prekonceptuális szintról a fogalmak szintjére jutni Lakoff szerint két módon lehetséges: a fizikairól az elvont területére történő metaforikus projekció, illetve az alapszintû kategóriáktól a magasabb, illetve alacsonyabb szintû kategóriákra történó projekció révén. „Az absztrakt fogalmi struktúrák indirekt módon tesznek szert jelentésre; a direkt módon jelentéses struktúrákkal való szisztematikus kapcsolatuk miatt értjük meg óket" (Lakoff 1990, 268).

\footnotetext{
${ }^{12}$ L. az alapszintí kategóriák összefoglaló jellemzését: Lakoff 1990, 46.

${ }^{13}$ L. Lakoff 1990, 271-280.
} 
Kulcsfogalomnak tekinthetjük a megtestesülés fogalmát, amennyiben egyfelól fogalmaink az ember biológiai kapacitásának és sajátosságainak, fizikai és társadalmi tapasztalatainak a következményei, másfelól bizonyos fogalmak használata nem intellektuális, hanem sokkal inkább automatikus, nem tudatos múködés.

Láthatjuk, hogy Lakoff szoros kapcsolatot tételez föl fogalmaink és motoros aktivitásunk, illetve vizuális tapasztalataink között. Pierre Jacob és Marc Jeannerod vizualitással kapcsolatos kutatásaiból is világosan kitúnik a motoros funkciók jelentősége, illetve a vizuális és a verbális reprezentáció különbsége. Az általuk kidolgozott elmélet, melyet a vizuális elme reprezentációs elméleteként tartanak számon, különbséget tesz vizuális és vizuomotoros reprezentáció között. Az elóbbi olyan magasabb kognitív funkciókhoz szolgáltat információt, mint pl. a kategorizáció, a fogalmi gondolkodás vagy az érvelés, míg az utóbbi a cselekvés szolgálatában áll (Jacob et al. 2004, 45). Egyik reprezentáció tartalma sem fogalmi, noha mindkettő szolgálhat fogalmi feldolgozás alapjául, illetve fogalmi úton feldolgozható. A szerzók a vizuális percepció finom árnyaltságát és információgazdagságát hangsúlyozzák a fogalmi feldolgozás során létrejövố tartalomhoz képest. Azaz a vizuális percepció útján nyert információk gondolattá való transzformálása csakis tetemes információvesztéssel mehet végbe, hiszen a vizuális percepció által nyert információ sokkal szerteágazóbb és részletesebb, mint ami bizonyos fogalmisággal megragadható, gondolatként kifejezhetô. (Két tárgy egymáshoz való viszonyának fogalmakkal való reprezentációja például számos olyan információ elhagyását jelenti, amelyek nélkül a vizuális percepció szolgáltatta információ elő sem állhatna. Ahhoz, hogy két tárgy egymáshoz való viszonya megragadható legyen, a tárgyak formája, nagysága, színe stb. mind adott mint piktoriális/ikonikus tartalom.) Ugyanakkor a vizuális percepció piktoriális tartalmának fogalmi tartalommá való alakítása közben újabb gondolati tartalom adódik az épp alakuló percepcióhoz, jelesül valamiféle reflexív egocentrikus perspektíva. Azaz a fogalmi tartalommá való alakulás egyben bizonyos reflexíven kezelt viszonyt, helyzetet is kifejez az adott tényálláshoz (Jacob et al. 2004, 31).

A vizuális és a vizuomotoros reprezentáció funkcionális különbsége mellett lényeges a referenciális keretük különbsége is. Azaz a vizuális reprezentáció a környezetról úgy nyújt információt, hogy a környezet különbözô elemeinek egymáshoz való viszonyát, a tárgyak elrendezettségét tekinti; míg a vizuomotoros reprezentáció az észlelố szempontjából, egocentrikusan jeleníti meg környezetének bizonyos elemeit úgy, hogy a manipulálhatóság feltételei váljanak világossá. A reprezentációs módok közötti váltás nyilvánvalóan egyszerú aktus, noha az agy bizonyos sérülései akadályozhatják. Figyelemreméltó ugyanakkor, hogy a fogalmi feldolgozás során megjelenô egocentrikus perspektíva lényegesen különbözik a vizuomotoros reprezentáció egocentrikus referenciájától. Az elóbbi reflexív és helyzetenként tudatosan konvertálható, míg az utóbbi spontán, s csak a tényleges fizikai helyzet változásával módosul.

A vizuális percepció során tehát egyfelól fontos szerephez jut pragmatikus irányultságunk, másfelól számos apró részlet észlelése gazdag információval lát el bennünket környezetünkkel kapcsolatban. Ezen észleletek fogalmi feldolgozása során bizonyos információk elvesztése árán distanciált leírását kapjuk a helyzetnek. E distancia szükségképp adódik abból a sajátos helyzetból, hogy a képi információ fogalmi transzformációja egy lényegesen szúkebb tartományra való leképezést jelent, illetve hogy ez a leképezés bizonyos perspektíva, szándék fényében történik. Miképp Michael 
Tomasello a Gondolkodás és kultúra címú könyvében - a nyelvi reprezentáció speciális vonásait az ember egyedfejlődésének, illetve a fớemlősök és a humán kognició különbségének fényében tárgyalva - felhívta rá figyelmünket, a beszéd feltételez bizonyos szándékot, illetve e szándék függvényében képvisel bizonyos nézópontot, perspektívát. A nyelvi reprezentáció nem a különféle érzékszervi és kinetikus tapasztalatok egyszerú rögzítésén nyugszik, hanem az egyéneknek az adott helyzethez kapcsolódó választásán, hogy ti. milyen perspektíva felel meg leginkább céljaik szempontjából a jelenségek értelmezésének. ${ }^{14}$

Ezzel szemben a vizuális percepciót feldolgozó reprezentációk vagy pragmatikusak, tehát adott helyzetben való cselekvéshez kötöttek, vagy lényegében olyan ikonikus tartalmat közvetítenek, amelyek információgazdagságuk révén különféle fogalmi feldolgozások alapjául szolgálhatnak.

Allan Paivio, aki a képi és a nyelvi folyamatokat a szimbolikus reprezentáció alternatív módjainak tekinti, a kettố párhuzamos, egymást segítô-kiegészítô funkcióját hangsúlyozza. Érdekes problémát vet föl Berlyne-t idézve, aki a verbális reprezentációt nem tekintette igazán hatékonynak bizonyos transzformációk megragadásában. Paivio e különbségtevéssel azért nem tudott maradéktalanul egyetérteni, mert nem látta kellóképp bizonyítottnak, hogy a motoros aktivitás szorosabban kapcsolódik a képi reprezentációhoz, mint a verbálishoz ${ }^{15}$ E problémára választ találhatunk Jacob és Jeannerod kutatásaiban, hiszen azok a vizuomotoros reprezentációkat egyértelmúen (noha nem kizárólagosan) a motoros aktivitáshoz kapcsolták. A vizuális percepció és a vizuomotoros reprezentáció között tett különbség által nyilvánvalóvá vált, hogy noha mindkettố szolgálhat fogalmi feldolgozás alapjául, s mindkettô segítheti motoros tevékenységünket, bármilyen motoros aktivitás meglehetôsen fáradságos és nehézkes vizuomotoros reprezentáció nélkül. Ugyanakkor a vizuális percepció fogalmi feldolgozása nem igényel feltétlen vizuomotoros reprezentációt. Tehát a vizualitás a vizuomotoros reprezentáció révén lényegesen közvetlenebb viszonyban van a motoros aktivitással, mint a fogalmi/nyelvi feldolgozás, a motoros aktivitás pedig (akár elözményként, akár következményként) szorosan összefügg a transzformáció jelenségével. Ez természetesen nem azt jelenti, hogy motoros aktusainkban ne lehetne szerepe a fogalmi reprezentációnak, mindössze arra világít rá, hogy fokozatbeli különbség tapasztalható ott, ahol Paivio nem látta bizonyítottnak a különbséget.

Lakoff ötféle kognitív modellt különböztet meg. Ezek a propozicionális, a vázlatos-képi, a metaforikus, a metonimikus és a szimbolikus. ${ }^{16} \mathrm{Az}$ elsố kettố a struktúrát határozza meg, a másik kettô pedig a leképezést írja le.

„A propozicionális modellek - írja Lakoff - rendelkeznek bizonyos objektivista színezettel, hiszen tulajdonságokkal bíró entitásokat és köztük levố relációkat tartalmaznak. [...] Úgy túnik számomra, hogy amikor tapasztalatainkat propozíciós

\footnotetext{
${ }^{14}$ Vö. ,[a] nyelvi szimbólumok interszubjektív és perspektivikus természete egész egyszerúen megszünteti a perceptuális helyzet fogalmát, mert megtoldja a használók rendelkezésére álló különféle lehetséges kommunikációs perspektívák új szintjeivel” (Tomasello 2002, 142).

${ }^{15}$ L. Paivio $1979,31$.

${ }^{16}$ Szimbolikus modellról akkor beszélünk, amikor a konceptuális elemekhez nyelvi elemek is kapcsolódnak. A másik négy esetben ugyanis szigorúan fogalmakról van szó. L. Lakoff 1990, 289.
} 
modelleknek a rájuk való projektálásával értjük meg, valamiféle objektivista struktúrát erốltetünk a világra" (Lakoff 1990, 285).

Tehát a nyelv struktúrája alapvetôen nem mond ellent a predikátumlogika szabályainak (a mondat szerkezetét mégiscsak az alany-állítmány szerkezet határozza meg), noha kognitív kapacitásunk és - Heidegger terminusával élve - a világban való tevés-vevés létünk egyik alapmeghatározottsága, E predikátumlogika múködését feltétlenül meghatározza az a kognitív struktúra, amely alapja és feltétele e predikátumlogikának, de a nyelv múködése s késóbb az írásbeliség hosszú évszázadai szinte teljesen elfeledtették, hogy a betúk világán túl található gondolkodásunk gyökere. Jól bizonyítja e feledékenység a reprezentáció módjának jelentôségét.

A nyelv félrevezetô, torzító sajátosságait illetôen Wittgenstein 1932-35 között Cambridge-ben tartott elớadásaiban érdekes megfigyelésekról számol be. Már utaltam az elme jelentôségére a filozófia története során, $s$ Wittgenstein többek között épp az elmével kapcsolatos koncepciók mögött rejlő nyelvi buktatók megvilágításán fáradozik. Azt állítja, hogy akkor vagyunk leginkább kiszolgáltatva az eltévelyedésnek, amikor azt feltételezzük, hogy érzeteink valami módon az elménkben kapcsolódnak a szavakhoz. ${ }^{17} \mathrm{~A}$ tévedés pedig azáltal lehetséges, hogy a grammatika megengedi, hogy dologszerú és nem dologszerú entitásokat egyformán, fớnévként kezeljünk. Ekképp az elme - voltaképpen e nyelvtani hiányosság miatt - dologszerú entitásként szerepel, s így a dolgokra jellemzó térbeli konstellációkkal ruházzuk fel. Ez pedig félrevezetô és komoly bonyodalmakhoz vezethet, amiképp a filozófia történetében vezetett is.

\section{Újfajta racionalitás és kritikai attitüd}

A nyelv és a filozófiai problémák analízise mellett Wittgenstein természetesen leszögezi: igényeljük, hogy dolgokra rámutathassunk. Azaz sok esetben nem elegendốaz absztrakt definíció, jobb szolgálatot tehet az adott jelenséggel vagy tárggyal való közvetlen szembesülés. Wittgenstein használatorientált nyelvfelfogása, a percepció és a mindennapi motoros aktivitás szerepe a kategorizációban és a fogalomalkotásban mind azt mutatja, hogy lehetetlen feladatra vállalkozott a filozófia akkor, amikor elvont megfontolások alapján tökéletes nyelvet vagy a világot tökéletesen leírni képes logikai rendszert igyekezett kidolgozni. A nyelv múködését bizonyos szabályok határozzák meg, s itt nem elsősorban a grammatikára gondolok, hanem a nyelvnek és kognitív készségeinknek az összjátékára. A percepció és a motoros aktusok aktív, mondhatni teremtő szerepet töltenek be a nyelvi kategóriák kialakításában és azok használatában. A nyelvnek az eleven gyakorlattól való elszakadása, amelyben az írásbeliségnek döntố szerepe volt, számos téveszme forrásává vált. Ha Hajnal objektivációelméletére gondolunk, ez nem

17 „There are the sounds of the words, and all sorts of bodily sensations connected with gesture and intonation. Where we are liable to go wrong is in supposing that sensations connected with words are somehow 'in the mind'. The phrase 'in the mind' has caused more confusion than almost any other in philosophy" (Wittgenstein 1979, 114). 
is meglepó. A kiút valóban akkor sejlett föl, amikor a nézópontot, ha tetszik, a paradigmát váltották le: itt természetesen Wittgensteinre gondolok. De eszünkbe juthat Martin Heidegger, aki a metafizika destruálásával a világbavetettséget hangsúlyozta a tudat immanenciájából való kilépést sürgetve; s felidézhetjük Henri Bergson és John Dewey elméleti erófeszítéseit, akik koruk tudományos kutatásaira, illetve praktikus problémákra reflektálva rávilágítottak, hogy szükségessé vált az elme és a test hagyományos dualiz- musának felszámolása.

A filozófia felismerései, a kognitív tudomány és a kognitív pszichológia eredményei mára nyilvánvalóvá tették a perspektívaváltás elkerülhetetlenségét. Másfelól a technika lehetốvé teszi a verbalitás kényszerének enyhülését. Mit eredményezhetnek ezek a változások? - Annyi bizonyos, hogy a filozófia számára komoly kihívást jelent e helyzet, hiszen a fogalmi háló újraszerkesztését s ezzel együtt bizonyos metafizikai, ontológiai és ismeretelméleti elófeltevéseket kell újragondolnia.

E változások nem hagyják érintetlenül a nyugati elme kritikai hajlamát sem. A nyelv által sugallt és az írásbeliség által radikalizált distanciáló-elemző beállítódás a nyelvi kifejezés dominancijának enyhülésével halványulhat. Ha a gondolatok kifejezésének és közvetítésének lehetôsége kiterjed például a képek világára is, a szigorú szabályok szerint újrastrukturált információ helyét átveheti például az immerzív kép, amely pusztán a vizuális percepció sajátosságai miatt módosíthatja az értelmező attitúdjét. S az enyhülés jelei máris tapasztalhatók: a hagyományos kritikai attitûd mellett egyre erốteljesebben találkozhatunk olyan tudományos igényú szándékkal, amely az új kommunikációtechnológiai invenciókat integrálni igyekszik a még javarészt hagyományos keretek között múködő gyakorlatba. (Gondolhatunk például a világszerte szervezódó projektekre az internet- és mobilhasználat oktatásba való bevonását illetốen.) A multimodalitásnak köszönhetôen újra kezelhetôvé válnak azok a bizonyos részletek, amelyeknek hiánya a verbalitás dominanciája következtében a mindennapi gyakorlatot kezelhetetlenné s ezért kerülendóvé tette az elmélet számára. A környező világgal s annak feladataival való közvetlenebb viszony a távolságtartással szemben bizonyos involváltságot, mélyebb integrációt eredményez, s amint a racionalitás fogalma is módosulni látszik, a kritikai racionalitásnak legalábbis új módozatához vezethet.

\section{Irodalom}

Erdei Ferenc 1942. Történelem és szociológia, in Társadalomtudomány, 1942, 463-496.

Glatz Ferenc (szerk.) 1993. Technika, mívelödés. Tanulmányok. Budapest, História-MTA Történettudományi Intézet.

Ivins, William J. Jr. 2001. A nyomtatott képés a vizuális kommunikáció. Budapest, Enciklopédia Kiadó.

Kondor Zsuzsanna 2005a. Filozófia és nyelvi reprezentáció a kommunikációtechnológia fényében. In: Nyíri Kristóf és Palló Gábor (szerk.): Túl az iskolafilozófián. A 21. század bölcseleti élménye. Budapest: Áron Kiadó, 204-225.

Kondor Zsuzsanna 2005b. Social Makeup and Solitary Reason. In: Laczkó Sándor és Dékány András (szerk.): Lábjegyzetek Platónhoz, 4. A barátság. Szeged, Pro Philosophia Szegediensi Alapítvány Librarius, 317-330. 
Kondor Zsuzsanna 2007. Old Patterns, New Bewitchments. In: H. Hrachovec - A. Pichler - J. Wang (szerk.): Philosophy of the Information Society. Papers of the $3 d^{\text {th }}$ International Wittgenstein Symposium, 109-111.

Jacob, Pierre - Jeannerod Marc (2003), 2004. Ways of Seeing. The Scope and Limits of Visual Cognition. Oxford University Press.

Lakoff, George (1987), 1990. Women, Fire, and Dangerous Things. What Categories Reveal about the Mind. Chicago and London: The University of Chicago Press.

Ong, Walter J. (1982), 1983. Orality and Literacy: The Technologizing of the Word. London, Methuen.

Ong, Walter J. 1998. A szöveg mint interpretáció: Márk idején és azóta. In: Szóbeliség és írísbeliség. A kommunikációs technológiák története Homérosztól Heideggerig. szerk.: Nyíri Kristóf és Szécsi Gábor. Budapest, Áron Kiadó.

Paivio, Allan 1979. Imagery and Verbal Processes. Hillsdale, Lawrence Erlbaum Associate Publishers. Platón összes míivei, I-III 1984. Budapest, Európa.

Weber, Alfred 1927. Ideen zur Staats- und Kultursoziologie.

Wittgenstein, Ludwig 1979. Wittgenstein's Lectures. Cambidge, 1932-1935. Oxford, Basil Blackwell. Tomasello, Michael 2002. Gondolkodás és kultuira. Ford. Gervain Judit. Budapest, Osiris Kiadó. 